progenies of coastal Douglas-fir at $7 \frac{1}{2}$-years across Washington and Oregon, USA. Silvae Genet. 58: 212-219.

Gilmour, A. R., B. J. Gogel, B. R. Cullis and R. ThompSON (2006): ASREML User Guide Release 2.0 VSN International Ltd, Hemel Hempstead, HP1 1ES, UK.

Grossnickle, S. C. and R. FolK (2005): Stock quality assessment of a somatic interior spruce seedlot. North. J. Appl. For. 22: 197-202.

Gupta, P. K., R. Timmis, K. Timmis, W. Carlson, J. Grob and E. WELTY (1994): Plantlet regeneration via somatic embryogenesis in Douglas-fir (Pseudotsuga menziesii), pp. 35-39 in TAPPI Proc. Bio. Science Symposium. Norcross, GA.

Hargreaves, C. L., L. J. Grace, D. G. Holden (2002): Nurse culture for efficient recovery of cryopreserved Pinus radiata D. Don embryogenic cell lines. Plant Cell Reports 21: 40-45.

HöGBERG, K.-A. (2003): Somatic embryogenesis - A useful tool or extravagance? Pp. 12-16. In: Clonal Forestry: Who are You Kidding? Abstracts Conf. Nordic Group for the Manag. Genet. Res. of Trees, edited by T. EysteInsson. Barony Castle, Scotland, 4-7 September, 2002. IFRS Rept. 17/2003.

HuANG, C. L. (2005): System and method for measuring stiffness in standing trees. U.S. Patent No. 6,871,545. Washington, DC: US Patent and Trademark Office.
IsIK, F., B. Li BAILIAN and J. FrAmPTON (2003): Estimates of additive, dominance and epistatic genetic variances from a clonally replicated rest of loblolly pine. Forest Science 49: 77-88.

NAGMani, R., M. A. Johnson and R. J. Dinus (1991): Effect of explant and media on initiation, maintenance, and maturation of somatic embryos in Pseudotsuga menziesii var. menziesii (MIRB.) Franco (Douglas-fir), pp. 171-178. In: Woody Plant Biotechnology. Edited by M. R. Ahuja. Plenum Press, New York.

PARK, Y. S., J. D. BARRETT and J. M. Bonga (1998): Application of somatic embryogenesis in high-value clonal forestry: Deployment, genetic control, and stability of cryopreserved clones. In Vitro Cell. Dev. Biol. Plants 34: 231-239.

Patterson, H. D. and R. Thompson (1971): Recovery of interblock information when block sizes are unequal. Biometrika 58: 545-54.

Searle, S. R., G. Casella and C. E. McCulloch (1992): Variance Components. John Wiley and Sons: New York.

Stonecypher, R. W., R. F. Piesch, G. G. Helland, J. G. ChAPMAN and H. J. RENo (1996): Results from genetic tests of selected parents of Douglas-fir (Pseudotsuga menziesii [MIRB.] FrANCO) in an applied tree improvement program. For. Sci. Monograph 32: 1-35.

SutTon, B. (2002): Commercial delivery of genetic improvement to conifer plantations using somatic embryogenesis. Ann. For. Sci. 59: 657-661.

\title{
Genetic Parameters and Genotype by Environment Interaction in Radiata Pine for Growth and Wood Quality Traits in Australia
}

\author{
By B. S. Baltunis*'), W. J. Gapare and H. X. Wu \\ CSIRO Plant Industry, GPO Box 1600, Canberra, ACT 2604, Australia \\ Telephone: +612 6246 4823, Fax: +61262464564
}

(Received $12^{\text {th }}$ June 2009)

\begin{abstract}
The phenotypic response of genotypes across different environments can be quantified by estimating the genotype by environment interaction $(\mathrm{GxE})$. In a practical sense, GxE means that the relative performance of genotypes does not remain constant under all test conditions. Genetic parameters and genotype by environment interactions for wood density, growth, branching characteristics and stem straightness were investigated in eight radiata pine progeny trials derived from a second generation breeding population in Australia. Five trials were on the mainland, while three trials were in Tasmania. Generally, $\hat{h}^{2}$ for density > branch angle > stem straightness > tree diameter > branch size; and significant $\hat{h}^{2}$ was observed for all traits and at all trials with only two exceptions. Genetic correlations were estimated among
\end{abstract}

*) Corresponding author: Brian.Baltunis@csiro.au the five traits, and a large negative genetic correlation observed between wood density and tree diameter indicated that a selection strategy should be developed in dealing with this adverse genetic correlation in advanced generations of breeding for radiata pine.

Interactions for density, branch angle, and stem straightness were small within the two regions. Overall, branch angle had the least GxE, followed by density and stem straightness. Growth traits (tree diameter and branch size) tended to be the most interactive with substantial GxE present. Genotype by regional interactions (Mainland versus Tasmania) revealed that density and branch angle had the least interactions $\left(\hat{r}_{B}=0.98\right.$ and $\hat{r}_{B}=0.95$, respectively). Branch size and tree diameter had the highest interactions among the two regions $\left(\hat{r}_{B}=0.55\right.$ and $\hat{r}_{B}=0.63$, respectively). Within Tasmania, only branch size and tree diameter had a sizable interaction within the three sites. In contrast, there was little interaction for tree diameter among the Mainland 
trials. Branch size in the Mainland trials had a similar size of interaction as in Tasmania. Further research is recommended in identifying the cause of $\mathrm{GxE}$ for tree diameter and branch size in radiata pine across the entire radiata pine estate in Australia.

Key words: heritability, genetic correlations, genotype by environment interaction, Pinus radiata, growth, wood quality.

\section{Introduction}

The phenotypic response of genotypes across different environments can be quantified by estimating the genotype by environment interaction $(\mathrm{GxE})$. In a practical sense, $\mathrm{GxE}$ means that the relative performance of genotypes does not remain constant under all test conditions (e.g. BRIDGWATER and STONECYPHER, 1978). The patterns of response across environments may involve either change in the ranking of genotypes and/or alterations in scale (LYNCH and WALSH, 1998). BARNES et al. (1984) highlighted the importance of differentiating these causes of GxE as they influence subsequent decisions and strategy to be followed in dealing with the interactions. The assessment of GxE has been essential for formulating breeding and deployment strategies in forest trees (WHite et al., 1993). When present at family or clonal levels, GxE (rank change) is of particular concern to tree breeders since it determines critical decisions in developing optimal breeding and deployment strategies and realising genetic gains (WHITE et al., 2007).

The dilemma for tree breeders is that, on one hand, $\mathrm{GxE}$ tends to hamper progress by necessitating larger replication in space; while, on the other hand, a strong interaction offers the opportunity to increase genetic gains by developing specific genotypes which will perform well in specific environments. To deal with GxE in practical breeding programs, two general approaches have been suggested (RAYMOND and NAMKOONG, 1990). The first approach is to characterize the area and then choose the best genotypes for each site; this approach maximizes the yield over the total range of planting sites. The second approach is to find stable genotypes that perform well over all environments.

Numerous analytical methods have been developed to quantify the amount, source and significance of GxE for a breeding program (COOPER and DELACY, 1994). These include classical ANOVA which uses F-tests to determine statistical significance of $\mathrm{GxE}$ effects; regression analyses which examine the stability of genotype performance across environments; the ecovalence (Wricke's ecovalence) which examines the contribution of particular genotypes (or environments) to $\mathrm{GxE}$ sum of squares (e.g. Hodge, 1996); multiplicative mixed models approach (e.g. SMITH et al., 2001; 2005), GGE biplot analysis (DING et al., 2008), and BURDON's (1977) Type-B genetic correlation $\left(\mathrm{r}_{\mathrm{Bg}}\right)$. The Type-B genetic correlation approach has been discussed in detail in the literature (e.g. YAMADA, 1962; Eisen and SAXTON, 1983; Lu et al., 2001) and it continues to be one of the preferred methods for investigation of GxE in forestry experiments as it quantifies the role of environments in generating interactions (BURDON, 1977) and is easily implemented in a mixed model/BLUP setting where data are imbalanced which most of the other methods mentioned cannot handle.

In an effort to quantify the role of environments in generating interactions, substantial research on $\mathrm{GxE}$ in forest trees has been carried out, followed by several excellent reviews (e.g. SHELBOURne, 1972; BRIDGWATER and Stonecypher, 1978; BARNEs et al., 1984; MATHESON

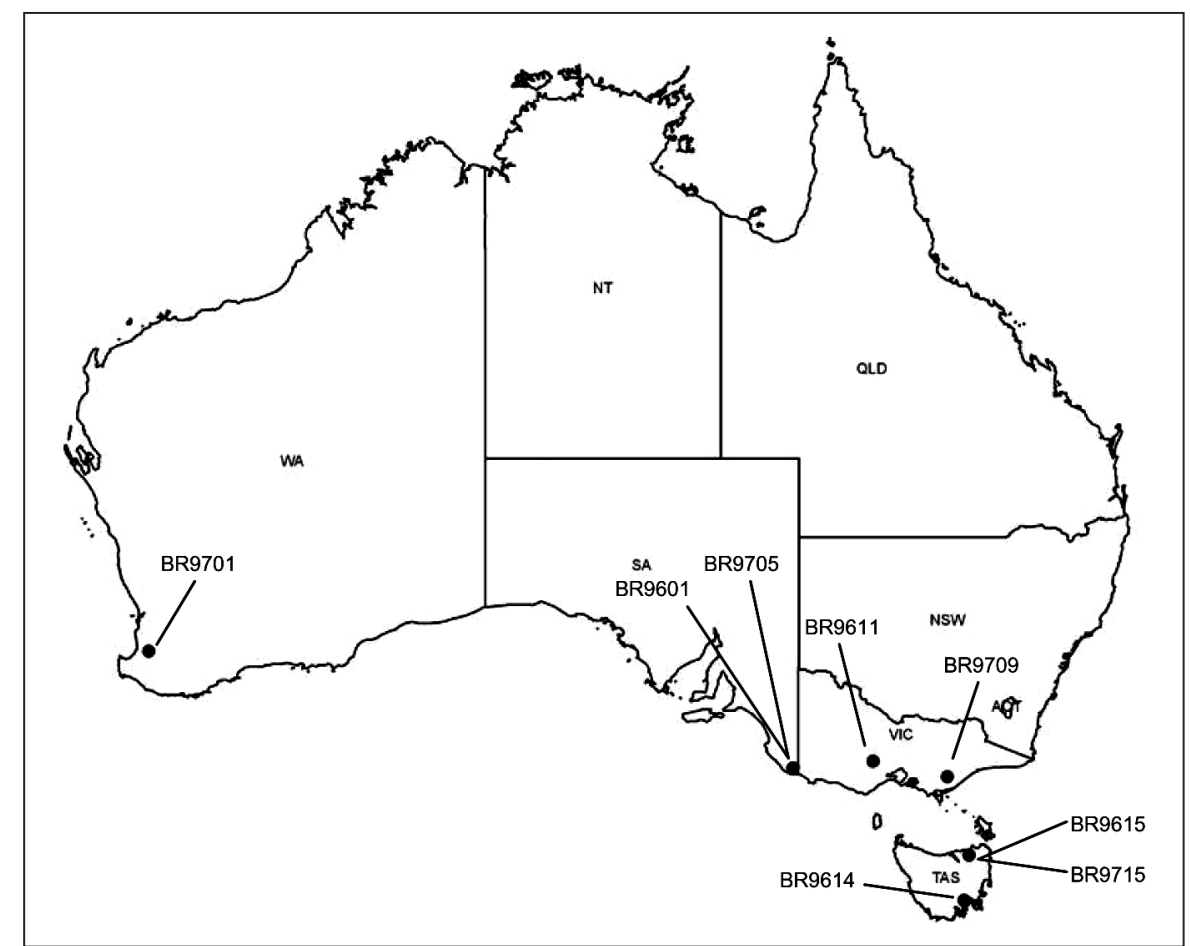

Figure 1. - Location of eight second-generation STBA radiata pine progeny trials in Australia. 
and COTTERILl, 1990; WoOlASTON et al., 1991; PSWARAYI et al., 1997; HoDGE and DvorAK, 1999). Other studies on GxE have sought to classify GxE as either "predictable" or "unpredictable" (e.g. JoHNSON and BURDON, 1990; CARson, 1991; Hodge and White, 1992; AdAM et al., 1994). Predictable GxE implies that environments can be classified into site types in such a way that Type-B genetic correlation is higher for pairs of environments of the same type than it is for pairs of environments of different types. For example, JoHnson and BuRDON (1990) examined GxE for 4.5 year old volume in four progeny tests of radiata pine (Pinus radiata D. Don) in New Zealand and reported six pairs of genetic correlations with an average $r_{\mathrm{Bg}}=0.55$. For the two pairs of sites on same soil type, the average $r_{B g}$ was 0.90 ; while for the four test pairs on different soils, $\mathrm{r}_{\mathrm{Bg}}$ averaged 0.38. In a larger radiata pine GxE study with 11 test sites in New Zealand, CARSON (1991) found no clear pattern of site combinations, i.e. no predictable GxE. One difficulty in identifying predictable patterns of $\mathrm{GxE}$ is the large number of tests needed in each type of environment.

GxE for radiata pine growth traits has been studied extensively (MATHESON and RAYMOND, 1984; JOHNSON and Burdon, 1990; CARson, 1991; Wu and Matheson, 2005). MATHESON and RAYMOND (1984) reported evidence of GxE for growth in radiata pine. Similarly, Wu and MAtheson (2005) reported GxE in growth and stem characteristics of radiata pine at ten sites. Two sites in New South Wales contributed disproportionately to the interactions compared with the other sites. There were some considerable changes in rank between families growing in New South Wales compared with the same families growing elsewhere, particularly involving about 10 parents (Wu and MATHESON, 2005). GAPARE et al. (2010) recently reported evidence of $\mathrm{GxE}$ for tree diame- ter growth at ages 20/21 years for radiata pine but little evidence of GxE for wood density across eight sites in Australia.

In the current study, the genetic variation associated with tree diameter at breast height, wood density, branch angle, branch size, and stem straightness was investigated for young radiata pine growing in eight second-generation progeny trials in Australia. Five trials were located in mainland Australia, while three were in Tasmania. To our knowledge, this is the first published reports of genetic parameters for these traits from radiata pine trials in Tasmania, and as a consequence, the extent of GxE for these traits is unknown between radiata pine trials in Tasmania and mainland Australia. The objectives of the study were to i) estimate heritability for tree diameter, wood density, branch angle, branch size, and stem straightness; ii) estimate genetic correlations among tree diameter, wood density, and form traits; and iii) investigate GxE for tree diameter, wood density, and form traits across a diverse range of sites with a particular focus between Australia mainland and Tasmania regions.

\section{Methods and Materials \\ Genetic material and measurements}

Current selection criteria used in the different selection indices for radiata pine breeding by the Southern Tree Breeding Association (STBA) in Australia include tree diameter, branch quality (size and angle), stem straightness, Phytophthora resistance, Dothistroma resistance and wood density (PowELL et al., 2004). These selection criteria are used to define rotation-age breeding objectives for radiata pine that include mean annual increment, stem straightness (or sweep), branch size,

Table 1. - Trial location and description of eight $2^{\text {nd }}$ generation radiata pine progeny trials and trait means \pm standard deviation for tree diameter, wood density, branch angle, branch size, and stem straightness. Branch angle was not measured at BR9715.

\begin{tabular}{|c|c|c|c|c|c|c|c|c|c|c|c|}
\hline \multirow[b]{2}{*}{ Trial $^{1}$} & \multirow[b]{2}{*}{ Location } & \multirow[b]{2}{*}{ Region } & \multirow[b]{2}{*}{$\begin{array}{l}\text { Elevation } \\
\text { (m) }\end{array}$} & \multirow{2}{*}{$\begin{array}{c}\text { Annual } \\
\text { Rainfall } \\
(\mathbf{m m})\end{array}$} & \multirow{2}{*}{$\begin{array}{l}\text { \# Full-sib/ } \\
\text { Polymix } \\
\text { Families }\end{array}$} & \multirow{2}{*}{$\begin{array}{c}\text { \# Obs. } \\
\text { (\# Density } \\
\text { Obs.) }\end{array}$} & \multicolumn{5}{|c|}{ Trait } \\
\hline & & & & & & & $\begin{array}{c}\text { Tree } \\
\text { Diameter } \\
(\mathbf{m m})\end{array}$ & $\begin{array}{c}\text { Wood } \\
\text { Density } \\
\left(\mathrm{kg} / \mathrm{m}^{3}\right)\end{array}$ & $\begin{array}{c}\text { Branch } \\
\text { Angle }\end{array}$ & $\begin{array}{l}\text { Branch } \\
\text { Size }\end{array}$ & $\begin{array}{c}\text { Stem } \\
\text { Straightness }\end{array}$ \\
\hline BR9601 & $\begin{array}{l}\text { Mt. } \\
\text { Gambier, } \\
\text { South } \\
\text { Australia }\end{array}$ & Mainland & 63 & 706 & $\begin{array}{l}143 \\
105\end{array}$ & $\begin{array}{c}4706 \\
(1254)\end{array}$ & $\begin{array}{l}149.6 \\
\pm 17.3\end{array}$ & $\begin{array}{l}333.7 \\
\pm 23.2\end{array}$ & $\begin{array}{c}3.46 \\
\pm 1.03\end{array}$ & $\begin{array}{c}3.44 \\
\pm 0.95\end{array}$ & $\begin{array}{c}3.48 \\
\pm 1.02\end{array}$ \\
\hline BR9611 & $\begin{array}{l}\text { Gippsland, } \\
\text { Victoria } \\
\end{array}$ & Mainland & 166 & 760 & $\begin{array}{c}154 \\
87 \\
\end{array}$ & $\begin{array}{c}3992 \\
(1891)\end{array}$ & $\begin{array}{r}153.1 \\
\pm 21.1 \\
\end{array}$ & $\begin{array}{r}364.0 \\
\pm 24.6 \\
\end{array}$ & $\begin{array}{c}3.43 \\
\pm 1.12 \\
\end{array}$ & $\begin{array}{c}3.54 \\
\pm 1.12 \\
\end{array}$ & $\begin{array}{c}3.55 \\
\pm 1.12 \\
\end{array}$ \\
\hline BR9701 & $\begin{array}{l}\text { Collie, } \\
\text { Western } \\
\text { Australia }\end{array}$ & Mainland & 204 & 937 & $\begin{array}{l}105 \\
147\end{array}$ & $\begin{array}{c}4936 \\
(1534)\end{array}$ & $\begin{array}{r}154.3 \\
\pm 26.6\end{array}$ & $\begin{array}{l}334.8 \\
\pm 22.6\end{array}$ & $\begin{array}{c}3.48 \\
\pm 1.14\end{array}$ & $\begin{array}{c}3.32 \\
\pm 1.12\end{array}$ & $\begin{array}{c}3.16 \\
\pm 1.21\end{array}$ \\
\hline BR9705 & $\begin{array}{l}\text { Mt. } \\
\text { Gambier, } \\
\text { South } \\
\text { Australia }\end{array}$ & Mainland & 55 & 900 & $\begin{array}{l}40 \\
70\end{array}$ & $\begin{array}{l}2091 \\
(880)\end{array}$ & $\begin{array}{r}170.5 \\
\pm 20.7\end{array}$ & $\begin{array}{r}317.4 \\
\pm 21.2\end{array}$ & $\begin{array}{c}3.48 \\
\pm 0.71\end{array}$ & $\begin{array}{c}3.42 \\
\pm 0.81\end{array}$ & $\begin{array}{c}3.40 \\
\pm 0.77\end{array}$ \\
\hline BR9709 & $\begin{array}{l}\text { Ballarat, } \\
\text { Victoria }\end{array}$ & Mainland & 435 & 691 & $\begin{array}{l}36 \\
72\end{array}$ & $\begin{array}{l}2051 \\
(510)\end{array}$ & $\begin{array}{r}171.9 \\
\pm 27.5\end{array}$ & $\begin{array}{l}341.1 \\
\pm 21.6\end{array}$ & $\begin{array}{c}3.36 \\
\pm 1.10\end{array}$ & $\begin{array}{c}3.55 \\
\pm 1.14\end{array}$ & $\begin{array}{c}3.68 \\
\pm 0.90\end{array}$ \\
\hline BR9614 & $\begin{array}{l}\text { Hobart, } \\
\text { Tasmania }\end{array}$ & Tasmania & 51 & 615 & $\begin{array}{c}127 \\
27 \\
\end{array}$ & $\begin{array}{c}4337 \\
(1173) \\
\end{array}$ & $\begin{array}{c}174.2 \\
\pm 28.0 \\
\end{array}$ & $\begin{array}{l}334.2 \\
\pm 23.6 \\
\end{array}$ & $\begin{array}{c}3.50 \\
\pm 1.08 \\
\end{array}$ & $\begin{array}{c}3.57 \\
\pm 1.27 \\
\end{array}$ & $\begin{array}{c}3.33 \\
\pm 1.21 \\
\end{array}$ \\
\hline BR9615 & $\begin{array}{l}\text { Scottsdale, } \\
\text { Tasmania }\end{array}$ & Tasmania & 198 & 991 & $\begin{array}{l}127 \\
104\end{array}$ & $\begin{array}{l}2614 \\
(313)\end{array}$ & $\begin{array}{c}166.4 \\
\pm 28.4\end{array}$ & $\begin{array}{l}335.5 \\
\pm 24.2 \\
\end{array}$ & $\begin{array}{c}3.48 \\
\pm 0.95\end{array}$ & $\begin{array}{c}3.59 \\
\pm 1.00\end{array}$ & $\begin{array}{c}3.54 \\
\pm 0.96\end{array}$ \\
\hline BR9715 & $\begin{array}{l}\text { Scottsdale, } \\
\text { Tasmania }\end{array}$ & Tasmania & 198 & 991 & $\begin{array}{c}57 \\
122\end{array}$ & $\begin{array}{l}3081 \\
(350)\end{array}$ & $\begin{array}{l}182.0 \\
\pm 34.4\end{array}$ & $\begin{array}{l}361.7 \\
\pm 24.6\end{array}$ & -- & $\begin{array}{c}3.46 \\
\pm 1.18\end{array}$ & $\begin{array}{c}3.88 \\
\pm 1.12\end{array}$ \\
\hline
\end{tabular}

${ }^{1}$ BR96\#\# trials were planted in 1996, while BR97\#\# trials were planted in 1997. 
and wood density (Ivković et al., 2006). Therefore, in the current study tree diameter, wood density, branch angle, branch size, and stem straightness were measured at eight radiata pine second-generation STBA progeny trials in Australia.

Two trials were located in South Australia, two in Victoria, one in Western Australia, and three in Tasmania (Fig. 1). The trials were planted in 1996 and 1997 (Table 1). Trials contained five replications, incomplete blocking, and 4- or 5-tree row plots. In total, progeny from 254 radiata pine selections from the STBA breeding population were tested across the eight sites. These 254 selections were crossed in a mixed mating design as described by WhITE et al. (1999) to generate 228 full-sib families and 221 polymix families (Table 1). On average, 121 parents were tested at each of the eight trials, and connectedness among pairs of trials (e.g. number of parental selections in common) ranged from $22 \%$ to $93 \%$ with an average of $42 \%$ parents in common across pairs of trials (Table 2).

Measurements were collected in 2004 at the eight trials. Tree diameter was measured at $1.3 \mathrm{~m}$ above ground. Gravimetric wood density was estimated from $12 \mathrm{~mm}$ cores. Form traits had the following classifications:

Branch angle was scored on a scale of 1 to 6 with $1=$ steepest branch angle, ..., 6 = flattest branch angle and flatter branch angles are preferable;

Branch size was scored on a scale of 1 to 6 with $1=$ biggest branches, ..., $6=$ smallest branches where small branch sizes are preferable;

Stem straightness was scored on a scale of 1 to 6 with $1=$ most crooked stems, $\ldots, 6=$ straightest stems where straighter stems are preferable.

\section{Statistical analyses and genetic parameters}

A series of four genetic analyses were conducted on the data using ASReml (GILMOUR et al., 2005). First, each trait from all of the trials (univariate, single-site) was analysed in order to estimate the genetic variance components, individual-tree narrow-sense heritability and standard errors associated with each trait. An individual-tree linear mixed-effects model was used:

$$
\begin{aligned}
y_{i j k l m n o}= & \mu+R_{i}+\operatorname{row}_{j(i)}+\operatorname{col}_{k(i)}+\text { tree }_{l} \\
& + \text { fam }_{m}+\text { plot }_{n}+e_{i j k l m n o}
\end{aligned}
$$

where $y_{i j k l m n o}$ is the individual tree measurement, $\mu$ is the overall mean, $R_{i}$ is the fixed effect of replication, row $_{j(i)}$ is the random effect of row $\sim N\left(0, \hat{\sigma}_{\text {row }}^{2}\right), \operatorname{col}_{k(i)}$ is the random effect of column $\sim N\left(0, \hat{\sigma}_{c o l}^{2}\right)$, tree $_{l}$ is the random additive genetic effect of individual tree $\sim N\left(0, \hat{\sigma}_{A}^{2}\right)$, $\mathrm{fam}_{m}$ is the random effect of full-sib family (specific combining ability) $\sim N\left(0, \hat{\sigma}_{\text {fam }}^{2}\right)$, plot $_{n}$ is the random effect of plot $\sim N\left(0, \hat{\sigma}_{\text {plot }}^{2}\right)$, and $e_{i j k l m n o}$ is the random residual effect $\sim N\left(0, \hat{\sigma}_{E}^{2}\right)$.

Observed variance components were used to estimate the causal variance components and individual-tree narrow-sense heritability for each trait:

$\hat{\sigma}_{A}^{2}=$ estimate of additive genetic variance,

$\hat{\sigma}_{D}^{2}=4 \hat{\sigma}_{\text {fam }}^{2}=$ estimate of dominance genetic variance,

$\hat{\sigma}_{G}^{2}=\hat{\sigma}_{A}^{2}+\hat{\sigma}_{D}^{2}=$ estimate of total genetic variance assuming no epistasis,

$\hat{\sigma}_{P}^{2}=\hat{\sigma}_{A}^{2}+\hat{\sigma}_{f a m}^{2}+\hat{\sigma}_{p l o t}^{2}+\hat{\sigma}_{E}^{2}=$ estimate of phenotypic variance, and

$\hat{h}^{2}=\frac{\hat{\sigma}_{A}^{2}}{\hat{\sigma}_{P}^{2}}$ estimate of individual-tree narrow-sense

Bivariate, single-site individual-tree linear mixedeffects models were used to estimate the genetic correlations between traits within a site:

$$
\mathbf{y}_{i}=\mathbf{X}_{i} \mathbf{b}_{i}+\mathbf{Z}_{m_{i}} \mathbf{m}_{i}+\mathbf{Z}_{n_{i}} \mathbf{n}_{i}+\mathbf{Z}_{a_{i}} \mathbf{a}_{i}+\mathbf{Z}_{f_{i}} \mathbf{f}_{i}+\mathbf{Z}_{p_{i}} \mathbf{p}_{i}+\mathbf{e}_{i}
$$

where $\mathbf{y}_{i}$ is the vector of observations indexed (i) by trait, $\mathbf{b}_{i}$ is the vector of fixed effects (mean and replications) and $\mathbf{X}_{i}$ is the known incidence matrix relating the observations in $\mathbf{y}_{i}$ to the fixed effects in $\mathbf{b}_{i}$ where

$$
\mathbf{X}_{i} \mathbf{b}_{i}=\left[\begin{array}{cc}
\mathbf{X}_{1} & \mathbf{0} \\
\mathbf{0} & \mathbf{X}_{2}
\end{array}\right]\left[\begin{array}{l}
\mathbf{b}_{1} \\
\mathbf{b}_{2}
\end{array}\right] \text {, }
$$

Table 2. - Number of parents (diagonal) with progeny tested and the percent of parents in common between pairs of trials (below diagonal) for eight second-generation radiata pine progeny trials in Australia.

\begin{tabular}{|c|c|c|c|c|c|c|c|c}
\hline & BR9601 & BR9611 & BR9701 & BR9705 & BR9709 & BR9614 & BR9615 & BR9715 \\
\hline BR9601 & $\mathbf{1 2 8}$ & & & & & & & \\
\hline BR9611 & $72 \%$ & $\mathbf{1 3 4}$ & & & & & & \\
\hline BR9701 & $33 \%$ & $29 \%$ & $\mathbf{1 7 1}$ & & & & & \\
\hline BR9705 & $26 \%$ & $22 \%$ & $57 \%$ & $\mathbf{1 0 3}$ & & & & \\
\hline BR9709 & $24 \%$ & $23 \%$ & $58 \%$ & $62 \%$ & $\mathbf{1 0 1}$ & & & \\
\hline BR9614 & $42 \%$ & $39 \%$ & $28 \%$ & $32 \%$ & $30 \%$ & $\mathbf{5 6}$ & & \\
\hline BR9615 & $93 \%$ & $71 \%$ & $32 \%$ & $26 \%$ & $26 \%$ & $42 \%$ & $\mathbf{1 2 3}$ & \\
\hline BR9715 & $26 \%$ & $32 \%$ & $82 \%$ & $66 \%$ & $65 \%$ & $27 \%$ & $27 \%$ & $\mathbf{1 5 2}$ \\
\hline
\end{tabular}


$\mathbf{m}_{i}$ is the vector of random row within replication effects

$$
\sim \operatorname{MVN}\left(\mathbf{0},\left[\begin{array}{cc}
\mathbf{I}_{r} \hat{\sigma}_{r o w_{1}}^{2} & \mathbf{0} \\
\mathbf{0} & \mathbf{I}_{r} \hat{\sigma}_{\text {row }_{2}}^{2}
\end{array}\right]\right),
$$

$\mathbf{n}_{i}$ is the vector of random column within replication effects

$$
\sim \operatorname{MVN}\left(\mathbf{0},\left[\begin{array}{cc}
\mathbf{I}_{c} \hat{\sigma}_{c o l_{1}}^{2} & \mathbf{0} \\
\mathbf{0} & \mathbf{I}_{c} \hat{\sigma}_{c v l_{2}}^{2}
\end{array}\right]\right),
$$

$\mathbf{a}_{i}$ is the vector of random additive effects of individual trees $\sim \operatorname{MVN}(\mathbf{0}, \mathbf{G} \otimes \mathbf{A})$ where

$$
\mathbf{G}=\left[\begin{array}{cc}
\hat{\sigma}_{A_{1}}^{2} & \hat{\sigma}_{A_{1} A_{2}} \\
\hat{\sigma}_{A_{1} A_{2}} & \hat{\sigma}_{A_{2}}^{2}
\end{array}\right]
$$

and $\mathbf{A}=$ numerator relationship matrix generated from the pedigree, $\mathbf{f}_{i}$ is the vector of random effects of fullsib family (specific combining ability) $\sim \operatorname{MVN}\left(\mathbf{0}, \mathbf{F} \otimes \mathbf{I}_{f}\right.$ ) where

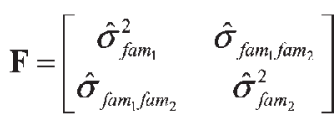

and $\mathbf{I}_{f}$ is an identity matrix equal to the number of families,

$\mathbf{p}_{i}$ is the vector of random plot effects

$$
\sim \operatorname{MVN}\left(\mathbf{0},\left[\begin{array}{cc}
\mathbf{I}_{p} \hat{\sigma}_{p l o t_{1}}^{2} & \mathbf{0} \\
\mathbf{0} & \mathbf{I}_{p} \hat{\sigma}_{\text {plot }}^{2}
\end{array}\right]\right),
$$

$\mathbf{e}_{i}$ is the random vector of residual terms $\sim M V N$ $(\mathbf{0}, \mathbf{R} \otimes \mathbf{I})$ where

$$
\mathbf{R}=\left[\begin{array}{cc}
\hat{\sigma}_{E_{1}}^{2} & \hat{\sigma}_{E_{1} E_{2}} \\
\hat{\sigma}_{F_{1} F_{2}} & \hat{\sigma}_{E_{2}}^{2}
\end{array}\right],
$$

$\mathbf{0}$ is the null matrix, $\mathbf{I}$ is the identity matrix equal to the number of observations; $\mathbf{I}_{r}, \mathbf{I}_{c}$, and $\mathbf{I}_{p}$ are identity matrices equal to the number of rows, columns, and plots, respectively; $\mathbf{Z}_{m_{i}}, \mathbf{Z}_{n_{i}}, \mathbf{Z}_{a_{i}}, \mathbf{Z}_{f_{i}}$, and $\mathbf{Z}_{p_{i}}$ are the known incidence matrices relating observations in $\mathbf{y}_{i}$ to effects in $\mathbf{m}_{i}, \mathbf{n}_{i}, \mathbf{a}_{i}, \mathbf{f}_{i}$, and $\mathbf{p}_{i}$, respectively.

The additive genetic correlation between traits was estimated as:

$$
\hat{r}_{A}=\frac{\hat{\sigma}_{A_{1} A_{2}}}{\sqrt{\hat{\sigma}_{A_{1}}^{2} \hat{\sigma}_{A_{2}}^{2}}}
$$

A multivariate, multi-site (all traits and all trials) analysis was also conducted in order to estimate additive genetic correlations between traits across all trials using a model similar to equation [2], except that here trial is a fixed effect.

In order to determine the extent of $\mathrm{GxE}$ for each of the traits, univariate, paired-site analyses were conducted and Type-B genetic correlations estimated using a model similar to equation [2], except trial is a fixed effect, and $\mathbf{y}_{i}$ is now defined as the vector of observations for a single trait indexed $(i)$ by trial. Type-B additive genetic correlations were then estimated as in BURDON (1977):

$$
\hat{r}_{B}=\frac{\hat{\sigma}_{A_{1} A_{2}}}{\sqrt{\hat{\sigma}_{A_{1}}^{2} \hat{\sigma}_{A_{2}}^{2}}}
$$

where values closer to unity indicate little genotype by environment interaction, and lower values indicate that genotype by environment interactions exist. For all estimates of genetic parameters, statistical significance was tested using F-tests.

There are many published manuscripts dealing with genetic parameters and $\mathrm{GxE}$ in radiata pine in Australia including WU and MATHESON (2005) in which they look at $\mathrm{GxE}$ for diameter growth across Australia (including Western Australia, but not Tasmania). The only regional pattern for GxE they observed was between New South Wales trials and non-New South Wales trials which they attributed to snow damage at the higher elevation trials in New South Wales. So trials in South Australia, Victoria, and Western Australia did not warrant dividing into sub-regions, but rather formed the non-New South Wales region. The unique aspect of our study is that these are the first published reports of genetic parameter for radiata pine from Tasmania, and therefore, the extent of $\mathrm{GxE}$ with non-Tasmania trials was an unknown. Based on this, we divided the trials into two regions: Tasmania and non-Tasmania (or Mainland trials) to explore $\mathrm{GxE}$ within and between regions.

\section{Results and Discussion}

Genetic variation for tree diameter, wood density, and form traits

Additive and non-additive (dominance) genetic variances were estimated for each trait at each trial. There was significant additive genetic variance $\left(\hat{\sigma}_{A}^{2}\right)$ estimated for tree diameter at each of the trials except at trial BR9709. $\hat{\sigma}_{A}^{2}$ ranged from 10.65 to 114.5 at the eight trials. Dominance genetic variance $\left(\hat{\sigma}_{D}^{2}\right)$ was only significant at four of the trials, and ranged from 0.24 to 137.0 at the eight trials. The ratio of $\hat{\sigma}_{A}^{2} / \hat{\sigma}_{D}^{2}$ varied across the eight trials. For example, at trials BR9615 and BR9701, this ratio was less than one, indicating $\hat{\sigma}_{D}^{2}$ associated with tree diameter was more important than $\hat{\sigma}_{A}^{2}$. Trials BR9601 and BR9611 had a $\hat{\sigma}_{A}^{2} / \hat{\sigma}_{D}^{2}$ for tree diameter equal to one, while the rest of the trials had $\hat{\sigma}_{A}^{2} / \hat{\sigma}_{D}^{2}$ greater than one for tree diameter.

There was substantial genetic variation for wood density at all of the trials. Additive genetic variance made up the majority of the genetic variation for density at six trials and was significant at all but trial BR9715 in Tasmania. At this trial, $\hat{\sigma}_{D}^{2}$ comprised $96 \%$ of the genetic variance for wood density which was rather unexpected. At the seven trials where $\hat{\sigma}_{A}^{2}$ was significant, $\hat{\sigma}_{A}^{2}$ ranged from 153.4 to 420.7. Dominance genetic variance was negligible for wood density at trials BR9601, BR9611, BR9615, BR9705, and BR9709. The ratio of $\hat{\sigma}_{A}^{2} / \hat{\sigma}_{D}^{2}$ for wood density was much greater than one at these trials. $\hat{\sigma}_{D}^{2}$ was significant at trials BR9701, BR9614, and BR9715. The ratio of $\hat{\sigma}_{A}^{2} / \hat{\sigma}_{D}^{2}$ for density was $1.25,0.83$, and 0.04 (essentially 0) at trials BR9614, BR9701, and BR9715, respectively.

Estimates of additive genetic variance for branch angle were significant at all seven trials where branch angle was measured. The range of $\hat{\sigma}_{A}^{2}$ was 0.1163 to 0.4321. Dominance genetic variance for branch angle 
Table 3. - Heritability estimates \pm standard error for tree diameter, wood density, branch angle, branch size, and stem straightness for eight second-generation radiata pine trials in Australia. Branch angle was not measured at BR9715. Statistical significance is indicated by: ${ }^{1} \mathrm{p}<0.10 ;{ }^{2} \mathrm{p}<0.05 ;{ }^{3} \mathrm{p}<0.01 ;{ }^{4} \mathrm{p}<0.001 ;{ }^{n}$ non-significant.

\begin{tabular}{cccccc}
\hline Trial & $\begin{array}{c}\text { Tree } \\
\text { Diameter }\end{array}$ & $\begin{array}{c}\text { Wood } \\
\text { Density }\end{array}$ & $\begin{array}{c}\text { Branch } \\
\text { Angle }\end{array}$ & $\begin{array}{c}\text { Branch } \\
\text { Size }\end{array}$ & $\begin{array}{c}\text { Stem } \\
\text { Straightness }\end{array}$ \\
\hline BR9601 & $0.22 \pm 0.05^{4}$ & $0.73 \pm 0.10^{4}$ & $0.29 \pm 0.05^{4}$ & $0.11 \pm 0.03^{4}$ & $0.23 \pm 0.04^{4}$ \\
BR9611 & $0.14 \pm 0.04^{4}$ & $0.73 \pm 0.08^{4}$ & $0.36 \pm 0.06^{4}$ & $0.18 \pm 0.04^{4}$ & $0.22 \pm 0.05^{4}$ \\
BR9701 & $0.09 \pm 0.03^{3}$ & $0.33 \pm 0.09^{4}$ & $0.22 \pm 0.05^{4}$ & $0.06 \pm 0.03^{2}$ & $0.17 \pm 0.04^{4}$ \\
BR9705 & $0.25 \pm 0.09^{3}$ & $0.48 \pm 0.15^{3}$ & $0.24 \pm 0.05^{4}$ & $0.16 \pm 0.05^{3}$ & $0.19 \pm 0.09^{2}$ \\
BR9709 & $0.01 \pm 0.04^{\mathrm{ns}}$ & $0.66 \pm 0.13^{4}$ & $0.19 \pm 0.09^{2}$ & $0.05 \pm 0.03^{1}$ & $0.12 \pm 0.09^{\mathrm{ns}}$ \\
BR9614 & $0.11 \pm 0.03^{4}$ & $0.55 \pm 0.16^{4}$ & $0.15 \pm 0.04^{4}$ & $0.09 \pm 0.03^{3}$ & $0.11 \pm 0.03^{4}$ \\
BR9615 & $0.14 \pm 0.04^{4}$ & $0.83 \pm 0.10^{4}$ & $0.27 \pm 0.05^{4}$ & $0.10 \pm 0.03^{4}$ & $0.15 \pm 0.04^{4}$ \\
BR9715 & $0.12 \pm 0.06^{2}$ & $0.04 \pm 0.19^{\mathrm{ns}}$ & -- & $0.07 \pm 0.04^{1}$ & $0.08 \pm 0.04^{2}$ \\
\hline $\begin{array}{c}\text { Multi-site } \\
\text { estimate }\end{array}$ & $0.10 \pm 0.02^{4}$ & $0.57 \pm 0.05^{4}$ & $0.20 \pm 0.03^{4}$ & $0.04 \pm 0.01^{4}$ & $0.12 \pm 0.02^{4}$ \\
\hline & & & & & \\
\hline
\end{tabular}

was significant only at trials BR9601 and BR9701. However, the ratio of $\hat{\sigma}_{A}^{2} / \hat{\sigma}_{D}^{2}$ for branch angle was 3.2 and 2.0 at BR9601 and BR9701, respectively. For branch size, $\hat{\sigma}_{A}^{2}$ was significant at all of the trials except BR9709, and $\hat{\sigma}_{A}^{2}$ ranged from 0.073 to 0.2181 . Dominance genetic variance, on the other hand, ranged from 0 to 0.115 , but was only significant at trials BR9601 and BR9701 which was the same as reported above for branch angle. However, the ratio of $\hat{\sigma}_{A}^{2} / \hat{\sigma}_{D}^{2}$ for branch size at these two trials was less than one. For stem straightness, $\hat{\sigma}_{A}^{2}$ was significant at six trials, while $\hat{\sigma}_{D}^{2}$ was only significant at trial BR9611. Estimates of additive genetic variance for stem straightness ranged from 0.0912 to 0.2814 across all eight trials. At BR9611, the ratio of $\hat{\sigma}_{A}^{2} / \hat{\sigma}_{D}^{2}$ was in excess of 2.1 .

\section{Individual-tree narrow-sense heritability $\left(\hat{h}^{2}\right)$}

Generally, $\hat{h}^{2}$ for wood density $>$ branch angle $>$ stem straightness $>$ tree diameter $>$ branch size; and significant $\hat{h}^{2}$ was observed for all traits and at all trials with a couple of exceptions (Table 3). For example, at trial BR9709 only wood density and branch angle had significant heritability estimates, and tree diameter was not significantly heritable. Additionally, at trial BR9715 only tree diameter and stem straightness were heritable. Significant values of $\hat{h}^{2}$ for tree diameter ranged from 0.09 to 0.25 across the trials (Table 3 ) with a mean $\hat{h}^{2}=0.15$ (or $=0.14$ if non-significant 0.01 estimate is included). Similar $\hat{h}^{2}$ for diameter growth was reported by MATHESON and RAYMOND (1984) in a population of 30 open-pollinated families of radiata pine tested across multiple sites $\left(\hat{h}^{2}=0.18\right)$. Moderately high and significant $\hat{h}^{2}$ was observed for wood density across all trials (Table 3) except at trial BR9715, where all of the genetic variance associated with wood density was non-additive. Significant values of $\hat{h}^{2}$ for wood density ranged from 0.33 to 0.83 (Table 3 ) with a mean $\hat{h}^{2}=0.62$ (or $=0.54$ if non-significant 0.04 estimate is included).
For branch angle, significant $\hat{h}^{2}$ was estimated at all of the trials where it was measured and ranged from 0.15 to 0.36 (Table 3 ), and mean $\hat{h}^{2}$ was 0.25 . Branch size was not as heritable as branch angle, and $\hat{h}^{2}$ ranged from a non-significant 0.05 to 0.18 (Table 3). Considering only significant values of $\hat{h}^{2}$ for branch size, the mean $\hat{h}^{2}$ was 0.12 (or $=0.10$ if non-significant estimates are included). Significant values of $\hat{h}^{2}$ for stem straightness ranged from 0.08 to 0.23 (Table 3 ) with a mean $\hat{h}^{2}=0.16$ (if nonsignificant 0.12 estimate is included, then $\hat{h}^{2}$ was still equal to 0.16). Heritability estimates may be upwardly biased when based on data from a single trial because they are confounded with $\mathrm{GxE}$ if it exists (Comstock and MolL, 1963). Therefore, multi-site heritability was also estimated for each trait and reported in Table 3.

\section{Genetic correlations $\left(\hat{r}_{A}\right)$}

Statistically significant genetic correlations were estimated between tree diameter and wood density, and $\hat{r}_{A}$ ranged between -0.23 to -0.57 across all trials (Table 4$)$. However, at BR9709, $\hat{r}_{A}$ was not significant $\left(\hat{r}_{A}=-0.23 \pm\right.$ 0.40 ). The genetic correlations between pairs of traits were also estimated from a multivariate, combined-site analysis (Table 5). From this analysis, tree diameter had a moderate, negative genetic correlation with wood density $\left(\hat{r}_{A}=-0.48 \pm 0.08\right)$. The adverse genetic correlation between tree diameter and wood density observed here is well within published estimates for radiata pine (DEAn et al., 1983; CotTerill and DEAN, 1990; Burdon and Low, 1992; JAYAWICKRAMA, 2001; KUMAR, 2004; LI and Wu, 2005; Baltunis et al., 2007). Additionally, Wu et al. (2008) recently reviewed estimates of genetic parameters in radiata pine and reported an average estimate of genetic correlation of -0.48 between growth and wood density which is the same as our multivariate, combined-site estimate. Similar negative genetic correlations (in the range of -0.4 ) have been observed in other 
Table 4. - Additive genetic correlation \pm standard error between pairs of traits for two-trait-single site analyses. Branch angle was not measured at BR9715. Bivariate analyses involving density at BR9715 failed to converge. Statistical significance is indicated by: ${ }^{1} \mathrm{p}<0.10 ;{ }^{2} \mathrm{p}<0.05 ;{ }^{3} \mathrm{p}<0.01 ;{ }^{4} \mathrm{p}<0.001 ;{ }^{\text {ns }}$ non-significant.

\begin{tabular}{|c|c|c|c|c|c|c|c|c|c|}
\hline \multirow[b]{2}{*}{ Trait 1} & \multirow[b]{2}{*}{ Trait 2} & \multicolumn{8}{|c|}{ Trial } \\
\hline & & BR9601 & BR9611 & BR9701 & BR9705 & BR9709 & BR9614 & BR9615 & BR9715 \\
\hline Tree Diameter & Wood Density & $\begin{array}{c}-0.52 \pm \\
0.13^{4}\end{array}$ & $\begin{array}{c}-0.57 \pm \\
0.13^{4}\end{array}$ & $\begin{array}{c}-0.39 \pm \\
0.19^{2}\end{array}$ & $\begin{array}{c}-0.46 \pm \\
0.14^{3}\end{array}$ & $\begin{array}{c}-0.23 \pm \\
0.40^{\mathrm{ns}}\end{array}$ & $\begin{array}{c}-0.51 \pm \\
0.21^{2}\end{array}$ & $\begin{array}{c}-0.51 \pm \\
0.16^{3}\end{array}$ & --- \\
\hline Tree Diameter & Branch Angle & $\begin{array}{r}0.63 \pm \\
0.11^{4}\end{array}$ & $\begin{array}{c}0.24 \pm \\
0.15^{\mathrm{ns}}\end{array}$ & $\begin{array}{c}0.60 \pm \\
0.15^{4}\end{array}$ & $\begin{array}{r}0.59 \pm \\
0.18^{3}\end{array}$ & --- & $\begin{array}{c}0.25 \pm \\
0.22^{\text {ns }}\end{array}$ & $\begin{array}{c}0.06 \pm \\
0.18^{\text {ns }}\end{array}$ & --- \\
\hline Tree Diameter & Branch Size & $\begin{array}{c}-0.74 \pm \\
0.09^{4}\end{array}$ & $\begin{array}{c}-0.17 \pm \\
0.18^{\text {ns }}\end{array}$ & $\begin{array}{r}-0.22 \pm \\
0.21^{\mathrm{ns}}\end{array}$ & $\begin{array}{c}-0.36 \pm \\
0.21^{1}\end{array}$ & --- & $\begin{array}{c}-0.23 \pm \\
0.23^{\text {ns }} \\
\end{array}$ & $\begin{array}{c}-0.50 \pm \\
0.14^{4}\end{array}$ & $\begin{array}{c}-0.50 \pm \\
0.17^{3} \\
\end{array}$ \\
\hline Tree Diameter & $\begin{array}{l}\text { Stem } \\
\text { Straightness }\end{array}$ & $\begin{array}{c}0.13 \pm \\
0.16^{\text {ns }}\end{array}$ & $\begin{array}{c}-0.30 \pm \\
0.17^{1}\end{array}$ & $\begin{array}{c}-0.01 \pm \\
0.20^{\text {ns }} \\
\end{array}$ & $\begin{array}{r}-0.04 \pm \\
0.20^{\text {ns }} \\
\end{array}$ & $\begin{array}{c}-0.15 \pm \\
0.65^{\mathrm{ns}} \\
\end{array}$ & $\begin{array}{c}0.38 \pm \\
0.20^{1} \\
\end{array}$ & $\begin{array}{r}0.41 \pm \\
0.20^{2} \\
\end{array}$ & $\begin{array}{c}0.12 \pm \\
0.34^{\mathrm{ns}}\end{array}$ \\
\hline Wood Density & Branch Angle & $\begin{array}{c}-0.10 \pm \\
0.14^{\mathrm{ns}} \\
\end{array}$ & $\begin{array}{c}-0.01 \pm \\
0.12^{\mathrm{ns}} \\
\end{array}$ & $\begin{array}{c}0.04 \pm \\
0.17^{\text {ns }} \\
\end{array}$ & $\begin{array}{c}-0.04 \pm \\
0.17^{\text {ns }} \\
\end{array}$ & $\begin{array}{c}-0.13 \pm \\
0.23^{\mathrm{ns}} \\
\end{array}$ & $\begin{array}{c}-0.40 \pm \\
0.22^{1} \\
\end{array}$ & $\begin{array}{c}0.01 \pm \\
0.14^{115} \\
\end{array}$ & --- \\
\hline Wood Density & Branch Size & $\begin{array}{c}0.15 \pm \\
0.17^{\text {ns }}\end{array}$ & $\begin{array}{c}0.09 \pm \\
0.14^{\mathrm{ns}}\end{array}$ & $\begin{array}{c}0.12 \pm \\
0.24^{\text {ns }}\end{array}$ & $\begin{array}{c}0.12 \pm \\
0.19^{\text {ns }}\end{array}$ & $\begin{array}{c}-0.09 \pm \\
0.28^{\mathrm{ns}}\end{array}$ & $\begin{array}{c}0.38 \pm \\
0.25^{\text {ns }}\end{array}$ & $\begin{array}{c}0.27 \pm \\
0.17^{\mathrm{ns}}\end{array}$ & --- \\
\hline Wood Density & $\begin{array}{l}\text { Stem } \\
\text { Straightness }\end{array}$ & $\begin{array}{c}-0.63 \pm \\
0.10^{4}\end{array}$ & $\begin{array}{r}-0.18 \pm \\
0.13^{\text {ns }}\end{array}$ & $\begin{array}{c}-0.34 \pm \\
0.17^{2}\end{array}$ & $\begin{array}{r}-0.31 \pm \\
0.21^{\mathrm{ns}}\end{array}$ & $\begin{array}{c}-0.19 \pm \\
0.23^{\text {ns }}\end{array}$ & $\begin{array}{c}-0.27 \pm \\
0.24^{\text {n1s }}\end{array}$ & $\begin{array}{c}-0.33 \pm \\
0.14^{2}\end{array}$ & --- \\
\hline Branch Angle & Branch Size & $\begin{array}{c}-0.33 \pm \\
0.15^{2}\end{array}$ & $\begin{array}{c}0.55 \pm \\
0.11^{4}\end{array}$ & $\begin{array}{c}0.58 \pm \\
0.17^{4}\end{array}$ & $\begin{array}{r}-0.11 \pm \\
0.19^{\text {ns }}\end{array}$ & $\begin{array}{c}0.77 \pm \\
0.16^{4}\end{array}$ & $\begin{array}{c}0.46 \pm \\
0.19\end{array}$ & $\begin{array}{c}0.27 \pm \\
0.17^{\mathrm{ns}}\end{array}$ & --- \\
\hline Branch Angle & $\begin{array}{l}\text { Stem } \\
\text { Straightness }\end{array}$ & $\begin{array}{c}-0.04 \pm \\
0.14^{\mathrm{ns}}\end{array}$ & $\begin{array}{c}0.15 \pm \\
0.14\end{array}$ & $\begin{array}{c}0.30 \pm \\
0.14^{2}\end{array}$ & $\begin{array}{c}-0.28 \pm \\
0.17^{1}\end{array}$ & $\begin{array}{c}0.09 \pm \\
0.27^{\mathrm{ns}}\end{array}$ & $\begin{array}{c}0.27 \pm \\
0.21^{1 \mathrm{ss}}\end{array}$ & $\begin{array}{c}0.04 \pm \\
0.16^{\mathrm{ns}}\end{array}$ & -- \\
\hline Branch Size & $\begin{array}{l}\text { Stem } \\
\text { Straightness }\end{array}$ & $\begin{array}{c}0.05 \pm \\
0.17^{\mathrm{ns}} \\
\end{array}$ & $\begin{array}{c}0.49 \pm \\
0.13^{4} \\
\end{array}$ & $\begin{array}{r}0.45 \pm \\
0.20^{2} \\
\end{array}$ & $\begin{array}{c}0.24 \pm \\
0.19^{\text {ns }} \\
\end{array}$ & $\begin{array}{c}0.37 \pm \\
0.29^{\text {ns }} \\
\end{array}$ & $\begin{array}{c}0.43 \pm \\
0.21^{\frac{2}{2}} \\
\end{array}$ & $\begin{array}{r}0.02 \pm \\
0.19^{\text {ns }} \\
\end{array}$ & $\begin{array}{r}-0.20 \pm \\
0.30^{\mathrm{ns}} \\
\end{array}$ \\
\hline
\end{tabular}

Table 5. - Additive genetic correlation \pm standard error between pairs of traits from multivariate, combined site analysis. Statistical significance is indicated by: ${ }^{1} \mathrm{p}<0.10 ;{ }^{2} \mathrm{p}<0.05 ;{ }^{3} \mathrm{p}<0.01 ;{ }^{4} \mathrm{p}<0.001 ;{ }^{\text {ns }}$ non-significant.

\begin{tabular}{|l|l|l|l|l}
\cline { 2 - 5 } \multicolumn{1}{c|}{} & Wood Density & Branch Angle & Branch Size & $\begin{array}{l}\text { Stem } \\
\text { Straightness }\end{array}$ \\
\hline Tree Diameter & $-0.48 \pm 0.08^{4}$ & $0.34 \pm 0.09^{4}$ & $-0.26 \pm 0.10^{2}$ & $-0.03 \pm 0.10^{\mathrm{ns}}$ \\
\hline Wood Density & & $-0.04 \pm 0.08^{\mathrm{ns}}$ & $0.10 \pm 0.10^{\mathrm{ns}}$ & $-0.28 \pm 0.08^{4}$ \\
\hline Branch Angle & & & $0.18 \pm 0.10^{1}$ & $-0.07 \pm 0.09^{\mathrm{ns}}$ \\
\hline Branch Size & & & & $0.27 \pm 0.10^{3}$ \\
\hline
\end{tabular}

conifers (e.g., LeE, 1997; Costa E Silva et al., 1998; ROZENBERG and CAHALAN, 1998; HANNRUP et al., 2000).

Tree diameter also had statistically significant genetic correlations with branch angle, and branch size. For example, $\hat{r}_{A}=0.34 \pm 0.09$ between tree diameter and branch angle from the combined-site analysis (Table 5). However, $\hat{r}_{A}$ between tree diameter and branch angle ranged from a non-significant 0.06 to 0.63 across individual trials (Table 4). A positive genetic correlation between tree diameter and branch angle indicate a favourable relationship between these two traits, i.e. trees ranking high for diameter also tended to rank high for flatter branch angles. Not surprisingly, larger diameter trees also tended to have bigger branches. This is indicated by the significant genetic correlation between tree diameter and branch size, $\hat{r}_{A}=-0.26 \pm 0.10$ (Table $5)$. Estimates of the genetic correlation between tree diameter and branch size ranged from a non-significant -0.17 to moderately high -0.74 across individual trials
(Table 4). A negative correlation between tree diameter and branch size indicates that larger trees also had large branches (e.g. low branch size score indicates larger branches). The genetic correlations between tree diameter and stem straightness were only significant at one of the trials in Tasmania (BR9615), while non-significant at all other trials (Table 4). Additionally, based on results from the combined-site analysis, tree diameter and stem straightness may be considered independent traits $\left(\hat{r}_{A}=-0.03 \pm 0.10\right)$.

There were no significant genetic correlations between wood density and branch angle, and wood density and branch size at any of the trials (Table 4). Generally, genetic correlation estimates between these traits were low with large standard errors in all single-site analyses and in the combined-site analysis. However, there was a significant genetic correlation between wood density and stem straightness based on the combined-site analysis, $\hat{r}_{A}=-0.28 \pm 0.08$ (Table 5). Genetic correlations between 
wood density and stem straightness ranged from a nonsignificant -0.13 to -0.63 across the individual trials (Table 4). This adverse genetic correlation implies that trees with higher wood density tended to have more crooked stems, perhaps a result of compression wood.

No clear trend was observed from the genetic correlation between branch angle and branch size based on single-site analyses. For example, although statistically significant estimates of the genetic correlation were observed, both negative and positive values were estimated, and $\hat{r}_{A}$ ranged from -0.33 to 0.77 across all trials (Table 4). Furthermore, the estimated genetic correlation between branch angle and branch size based on the combined-site analysis was non-significant $\left(\hat{r}_{A}=0.18 \pm\right.$ 0.10) (Table 5). Similarly, the genetic correlation between branch angle and stem straightness was not different than zero $\left(\hat{r}_{A}=-0.07 \pm 0.10\right)$ (Table 5), and only statistically significant at one trial (Table 4). Generally, the genetic correlations between branch size and stem straightness were positive with a range from a non-significant -0.20 to 0.49 , but only significant at three trials (Table 4). However, the combined-site estimate of the genetic correlation between branch size and stem straightness was significant, $\hat{r}_{A}=0.27 \pm 0.10$ (Table 5), indicating that some genotypes that ranked higher for stem straightness also ranked well for smaller branch size.

Genotype by environment interactions and Type-B genetic correlations $\left(\hat{r}_{B}\right)$

Among the five mainland trials, there was little evidence for $\mathrm{GxE}$ for tree diameter except between trials
BR9611 and BR9701 where $\hat{r}_{B}=0.48$ (Table 6). Type-B additive genetic correlations ranged from 0.48 to 1.4 between pairs of trials in the mainland (Table 6). However, there was some indication that parental rankings were unstable in the Tasmanian trials indicating GxE for tree diameter. For example, $\hat{r}_{B}$ ranged from 0.02 to 1.2 when estimated from at least one Tasmanian trial; but only a few Type-B genetic correlations involving the Tasmania trials were in excess of 0.71. (Table 6). Furthermore, Type-B genetic correlations for tree diameter involving measurements from trials BR9615 and BR9614 were all generally low indicating that GxE was present and that rank changes were occurring (Table 6). When trials were grouped within one of two regions, then $\hat{r}_{B}=0.63 \pm 0.11$ for tree diameter.

It is unclear what is causing the observed $\mathrm{GxE}$ for diameter growth in our study. Wu and MATHESON (2005) reported on $\mathrm{GxE}$ for diameter growth among AustralianWide-Diallel trials. They observed significant interaction and $\hat{r}_{B}$ ranged from -0.37 to 1.00 with an average $\hat{r}_{B}$ $=0.39$ (Wu and MATHESON, 2005). Furthermore, significant regional effects were observed, and two trials located in New South Wales had an average Type-B genetic correlation of 0.12 with non-New South Wales' trials, which may have been a result of snow damage which only affected trials at higher elevation in New South Wales (Wu and MAtheson, 2005). Similarly, MATHEson and RAYMOND (1984) reported significant GxE for diameter growth for 30 open-pollinated families of radiata pine tested across eleven trials in Australia with an overall $\hat{r}_{B}=0.33$. However, they recommended culling more interactive families from the breeding population

Table 6. - Type B genetic correlations \pm standard error for tree diameter between pairs of second-generation radiata pine progeny trials in Australia. Statistical significance is indicated by: ${ }^{1} \mathrm{p}<0.10 ;{ }^{2} \mathrm{p}<0.05 ;{ }^{3} \mathrm{p}<0.01 ;{ }^{4} \mathrm{p}<0.001 ;{ }^{\mathrm{n}}$ non-significant.

\begin{tabular}{|c|c|c|c|c|c|c|c|}
\hline & \multicolumn{4}{|c|}{ Region 1 - Mainland } & \multicolumn{3}{|c|}{ Region 2 - Tasmania } \\
\hline & BR9611 & BR9701 & BR9705 & BR9709 & BR9615 & BR9614 & BR9715 \\
\hline BR9601 & $\begin{array}{c}0.82 \\
\pm 0.12^{4}\end{array}$ & $\begin{array}{c}0.80 \\
\pm 0.15^{4}\end{array}$ & $\begin{array}{l}1.1 \\
\pm 0.06^{4}\end{array}$ & $\begin{array}{c}1.4 \\
\pm 1.9^{\mathrm{ns}}\end{array}$ & $\begin{array}{c}0.39 \\
\pm 0.18^{2}\end{array}$ & $\begin{array}{c}0.51 \\
\pm 0.17^{3}\end{array}$ & $\begin{array}{c}0.86 \\
\pm 0.23^{4}\end{array}$ \\
\hline BR9611 & & $\begin{array}{c}0.48 \\
\pm 0.23^{2}\end{array}$ & $\begin{array}{c}0.91 \\
\pm 0.15^{4}\end{array}$ & $\begin{array}{c}0.98 \\
\pm 0.60^{\mathrm{ns}} \\
\end{array}$ & $\begin{array}{c}0.48 \\
\pm 0.20^{2}\end{array}$ & $\begin{array}{c}0.24 \\
\pm \\
0.23^{\mathrm{ns}}\end{array}$ & $\begin{array}{c}0.56 \\
\pm 0.23^{2}\end{array}$ \\
\hline BR9701 & & & $\begin{array}{c}0.97 \\
\pm 0.17^{4}\end{array}$ & $\begin{array}{c}0.60 \\
\pm 0.50^{\mathrm{ns}}\end{array}$ & $\begin{array}{c}0.32 \\
\pm 0.25^{\mathrm{ns}}\end{array}$ & $\begin{array}{c}0.33 \\
\pm 0.23^{\mathrm{ns}}\end{array}$ & $\begin{array}{c}0.32 \\
\pm 0.29^{\mathrm{ns}}\end{array}$ \\
\hline BR9705 & & & & $\begin{array}{c}1.1 \\
\pm 0.48^{2}\end{array}$ & $\begin{array}{c}0.63 \\
\pm 0.20^{3}\end{array}$ & $\begin{array}{c}0.33 \\
\pm 0.27^{\mathrm{ns}}\end{array}$ & $\begin{array}{c}0.85 \\
\pm 0.12^{4}\end{array}$ \\
\hline BR9709 & & & & & $\begin{array}{c}0.66 \\
+0.62^{\mathrm{ns}} \\
\end{array}$ & $\begin{array}{c}0.02 \\
\pm 0.88^{\text {ns }} \\
\end{array}$ & $\begin{array}{c}1.2 \\
\pm \quad 1.1^{\mathrm{ns}} \\
\end{array}$ \\
\hline BR9615 & & & & & & $\begin{array}{c}0.44 \\
\pm 0.21^{2}\end{array}$ & --- \\
\hline BR9614 & & & & & & & $\begin{array}{c}0.71 \\
\pm 0.23^{3}\end{array}$ \\
\hline
\end{tabular}

Region 1 vs. Region 2 (all sites) $\hat{r}_{B}=0.63 \pm 0.11^{4}$. 
rather than having distinct regionalized breeding programs (MATHESON and RAYMOND, 1984). PEDERICK (1990) reported significant family by site interactions for tree diameter in radiata pine based on several trials in Victoria, Australia. However, GxE was not important for stem straightness and branch size. Type-B genetic correlations (averaged over two years) for tree diameter, stem straightness, and branch size were $0.46,0.90$, and 0.85 , respectively (PEDERICK, 1990; table 3). In New Zealand, significant family by environment interactions were observed in radiata pine between pumice and clay sites (JOHNSON and BURDON, 1990). In contrast, JOHNSON (1992) reported that family by environment interaction was not of practical importance for tree diameter and branch quality based on 73 half-sib families of radiata pine from three trials in New South Wales, Australia, and for stem straightness, significant interactions were attributable to 8 families.

There was no evidence for GxE for wood density across all pairwise combination of trials. Significant Type-B additive genetic correlations ranged from 0.74 to 1.0 for wood density $(p<0.001)$. There was also no genotype by region interaction for wood density with $\hat{r}_{B}=$ $0.98 \pm 0.02$. Generally, wood quality traits are believed to be genetically stable across trials. For example, BALTUNIS et al. (2007) previously reported Type-B genetic correlations $>0.77$ for wood density, modulus of elasticity, and microfibril angle based on SilviScan measurements between trials BR9601 and BR9705. Such high genetic correlations between sites for wood density indicate that parental rankings were stable, further suggesting that fewer trials may be necessary for ranking and selecting genotypes for wood density.
Similar trends were also seen for branch angle as were observed for wood density. For branch angle, statistically significant $\hat{r}_{B}$ ranged from 0.71 to 1.1 $(p<0.001)$ across all pairwise combination of trials, and no genotype by region interaction was present $\left(\hat{r}_{B}=0.95\right.$ $\pm 0.04)$. WU and MATHESON (2005) reported an average $\hat{r}_{B}=0.80$ for branch angle across the Australian-WideDiallel trials. However, there was some evidence of $\mathrm{GxE}$ for branch angle between certain pairs of trials $\left(\hat{r}_{B}\right.$ ranged from 0.31 to 1.1 ), but no clear regional trend (WU and MATHeson, 2005).

There was considerable GxE for branch size (Table 7). Type-B additive genetic correlations for branch size ranged from -0.13 to 1.1 . However, at some trials there was little additive genetic variance associated with branch size. Therefore, $\hat{r}_{B}$ had large standard errors and was non-significant in most cases (Table 7). Within the five mainland trials, when branch size measurements involved trial BR9705, there was generally low genotype by environment interaction. When trials were grouped into regions, the $\hat{r}_{B}=0.55 \pm 0.15$. Similarly, an average $\hat{r}_{B}=0.59$ was reported by WU and MATHESON (2005) for branch size in the Australian-Wide-Diallel trials.

There was some indication of instability of parental rankings across trials for stem straightness, but generally, moderately high $\hat{r}_{B}$ was observed in both regions (Table 8). For example, $\hat{r}_{B}$ ranged from 0.41 to 1.2 . Most of the lower values of $\hat{r}_{B}$ (ranging from 0.41 to 0.57 ) occurred with stem straightness measurements from Tasmanian trials (Table 8). However, when trials were grouped within regions, the $\hat{r}_{B}=0.76 \pm 0.07$ indicating that overall parental rankings were stable across Tasmanian and mainland trials.

Table 7. - Type B genetic correlations \pm standard error for branch size between pairs of second-generation radiata pine progeny trials in Australia. Statistical significance is indicated by: ${ }^{1} \mathrm{p}<0.10 ;{ }^{2} \mathrm{p}<0.05 ;{ }^{3} \mathrm{p}<0.01 ;{ }^{4} \mathrm{p}<0.001 ;{ }^{\text {ns }}$ non-significant.

\begin{tabular}{|c|c|c|c|c|c|c|c|}
\hline & \multicolumn{4}{|c|}{ Region 1 - Mainland } & \multicolumn{3}{|c|}{ Region 2 - Tasmania } \\
\hline & BR9611 & BR9701 & BR9705 & BR9709 & BR9615 & BR9614 & BR9715 \\
\hline BR9601 & $\begin{array}{c}0.39 \\
\pm 0.20^{1}\end{array}$ & $\begin{array}{c}0.43 \\
\pm 0.26^{1}\end{array}$ & $\begin{array}{c}0.96 \\
\pm 0.13^{4}\end{array}$ & $\begin{array}{c}-0.13 \\
\pm 0.41^{\text {ns }}\end{array}$ & $\begin{array}{c}-0.01 \\
\pm 0.22^{\mathrm{ns}}\end{array}$ & $\begin{array}{c}0.56 \\
\pm 0.19^{3}\end{array}$ & $\begin{array}{c}0.80 \\
\pm 0.21^{4}\end{array}$ \\
\hline BR9611 & & $\begin{array}{l}1.1 \\
\pm 0.10^{4}\end{array}$ & $\begin{array}{c}0.85 \\
\pm 0.20^{4}\end{array}$ & $\begin{array}{c}0.46 \\
\pm 0.30^{\mathrm{ns}}\end{array}$ & $\begin{array}{c}0.59 \\
\pm 0.16^{4}\end{array}$ & $\begin{array}{c}0.50 \\
\pm 0.21^{2}\end{array}$ & $\begin{array}{c}0.23 \\
\pm 0.28^{\mathrm{ns}}\end{array}$ \\
\hline BR9701 & & & $\begin{array}{c}1.1 \\
\pm 0.27^{4}\end{array}$ & $\begin{array}{c}0.70 \\
\pm 0.30^{2}\end{array}$ & $\begin{array}{c}0.45 \\
\pm 0.27^{1}\end{array}$ & $\begin{array}{c}0.56 \\
\pm 0.28^{2}\end{array}$ & $\begin{array}{c}0.19 \\
\pm 0.28^{\text {ns }}\end{array}$ \\
\hline BR9705 & & & & $\begin{array}{c}0.57 \\
\pm 0.30^{2}\end{array}$ & $\begin{array}{c}0.53 \\
\pm 0.24^{2}\end{array}$ & $\begin{array}{c}0.49 \\
\pm 0.29^{1}\end{array}$ & $\begin{array}{c}0.28 \\
\pm 0.27^{1 \mathrm{ss}}\end{array}$ \\
\hline BR9709 & & & & & $\begin{array}{c}0.51 \\
\pm 0.34^{\mathrm{ns}}\end{array}$ & $\begin{array}{c}0.21 \\
\pm 0.42^{\mathrm{ns}}\end{array}$ & $\begin{array}{c}0.21 \\
\pm 0.38^{\text {ns }}\end{array}$ \\
\hline BR9615 & & & & & & $\begin{array}{c}0.43 \\
\pm 0.24^{1}\end{array}$ & $\begin{array}{c}0.45 \\
\pm 0.31^{\text {ns }}\end{array}$ \\
\hline BR9614 & & & & & & & $\begin{array}{c}0.61 \\
\pm 0.30^{2}\end{array}$ \\
\hline
\end{tabular}

Region 1 vs. Region 2 (all sites) $\hat{r}_{B}=0.55 \pm 0.15^{4}$. 
Table 8. - Type B genetic correlations \pm standard error for stem straightness between pairs of second-generation radiata pine progeny trials in Australia. Statistical significance is indicated by: ${ }^{1} \mathrm{p}<0.10 ;{ }^{2} \mathrm{p}<0.05 ;{ }^{3} \mathrm{p}<0.01 ;{ }^{4} \mathrm{p}<0.001$; ${ }^{\text {ns non- }}$ significant.

\begin{tabular}{|c|c|c|c|c|c|c|c|}
\hline & \multicolumn{4}{|c|}{ Region 1 - Mainland } & \multicolumn{3}{|c|}{ Region 2 - Tasmania } \\
\hline & BR9611 & BR9701 & BR9705 & BR9709 & BR9615 & BR9614 & BR9715 \\
\hline BR9601 & $\begin{array}{c}0.93 \\
\pm 0.05^{4}\end{array}$ & $\begin{array}{c}0.88 \\
\pm 0.07^{4}\end{array}$ & $\begin{array}{c}0.98 \\
\pm 0.07^{4}\end{array}$ & $\begin{array}{c}0.82 \\
\pm 0.14^{4}\end{array}$ & $\begin{array}{c}0.77 \\
\pm 0.09^{4}\end{array}$ & $\begin{array}{c}0.62 \\
\pm 0.15^{4}\end{array}$ & $\begin{array}{c}0.57 \\
\pm 0.23^{2}\end{array}$ \\
\hline BR9611 & & $\begin{array}{c}0.89 \\
\pm 0.10^{4}\end{array}$ & $\begin{array}{c}0.84 \\
\pm 0.16^{4}\end{array}$ & $\begin{array}{c}0.73 \\
\pm 0.18^{4}\end{array}$ & $\begin{array}{c}0.75 \\
\pm 0.10^{4}\end{array}$ & $\begin{array}{c}0.53 \\
\pm 0.17^{3}\end{array}$ & $\begin{array}{c}0.68 \\
\pm 0.22^{3}\end{array}$ \\
\hline BR9701 & & & $\begin{array}{c}0.86 \\
\pm 0.10^{4}\end{array}$ & $\begin{array}{c}0.59 \\
\pm 0.19^{3}\end{array}$ & $\begin{array}{c}0.83 \\
\pm 0.10^{4}\end{array}$ & $\begin{array}{c}0.67 \\
\pm 0.16^{4}\end{array}$ & $\begin{array}{c}0.57 \\
\pm 0.22^{2}\end{array}$ \\
\hline BR9705 & & & & $\begin{array}{c}0.81 \\
\pm 0.13^{4}\end{array}$ & $\begin{array}{c}0.55 \\
\pm 0.21^{3}\end{array}$ & $\begin{array}{c}0.56 \\
\pm 0.29^{1}\end{array}$ & $\begin{array}{c}0.72 \\
\pm 0.27^{2}\end{array}$ \\
\hline BR9709 & & & & & $\begin{array}{c}0.91 \\
\pm 0.16^{4}\end{array}$ & $\begin{array}{c}0.71 \\
\pm 0.22^{3}\end{array}$ & $\begin{array}{c}0.41 \\
\pm 0.33^{\mathrm{ns}}\end{array}$ \\
\hline BR9615 & & & & & & $\begin{array}{c}0.87 \\
\pm 0.15^{4}\end{array}$ & $\begin{array}{c}0.87 \\
\pm 0.23^{4}\end{array}$ \\
\hline BR9614 & & & & & & & $\begin{array}{l}1.2 \\
\pm 0.20^{4}\end{array}$ \\
\hline
\end{tabular}

Region 1 vs. Region 2 (all sites) $\hat{r}_{B}=0.76 \pm 0.07^{4}$.

\section{Conclusion}

Tree diameter, wood density, branch angle, branch size, and stem straightness in radiata pine were under genetic control for progenies derived from the secondgeneration of breeding. Significant additive genetic variance was estimated indicating that selection will be effective for the third generation breeding population and large improvement in these traits is possible from the second to the third generation breeding population. Generally, $\hat{h}^{2}$ for density $>$ branch angle $>$ stem straightness $>$ tree diameter > branch size; and significant $\hat{h}^{2}$ was observed for all traits and at all trials with only two exceptions. The large negative genetic correlation observed between wood density and tree diameter indicated that a selection strategy should be developed in dealing with this adverse genetic correlation in advanced generations of breeding for radiata pine. There was little evidence of GxE for wood density, branch angle, and stem straightness. However, there was some evidence of GxE for tree diameter in the Tasmanian trials and for branch size across all trials. Further research is recommended in identifying the cause of $\mathrm{GxE}$ for tree diameter and branch size in radiata pine not only in these trials but across the entire radiata pine estate in Australia. Certain families may be more interactive than others depending on site quality (e.g. soil type, nutrition, rainfall, elevation, etc.). Identification of the causal components, genotypic and environmental, that are driving GxE for radiata pine growth traits can be incorporated along with bioeconomic selection indices into optimizing breeding and deployment strategies for radiata pine in Australia.

\section{Acknowledgements}

We wish to thank Forest Wood Products Association, Southern Tree Breeding Association, and CSIRO for funding the project. Special thanks to TONY MCRAE and Mike Powell from STBA for access to trial data. Also, thanks to ForestrySA, Forest Products Commission, Hancock Victorian Plantations, Green Triangle Forest Products, Forestry Tasmania, and Norske Skog for trial maintenance and assessments. We acknowledge the helpful reviews of an earlier draft by Colin MATHESON, DAVID Bush, Kevin HARDING and two anonymous referees.

\section{References}

Adams, W. T., T. L. White, G. R. Hodge and G. L. Powell (1994): Genetic parameter for bole volume in longleaf pine: Large sample estimates and influences of test characteristics. Silvae Genet. 43: 357-366.

Baltunis, B. S., H. X. Wu and M. B. Powell (2007): Inheritance of density, microfibril angle, and modulus of elasticity in juvenile wood of Pinus radiata at two locations in Australia. Can. J. For. Res. 37: 2164-2174.

Barnes, R. D., J. Burley, G. L. Gibson and Garcia DE LEON (1984): Genotype-Environment Interaction in Tropical pines and their effects on the structure of breeding populations. Silvae Genet. 33: 186-198.

Bridgwater, F. E. and R. W. Stonecypher (1978): Genotype $\mathrm{x}$ environment interaction: Implications in tree breeding. In: Proc. Of the $5^{\text {th }}$ North American Forest Biology Workshop, University of Florida, Gainesville, March 13-15, 1978: 46-63. 
BuRDON, R. D. (1977): Genetic correlation as a concept for studying genotype-environment interaction in forest tree breeding. Silvae Genet. 26: 168-175.

Burdon, R. D. and C. B. Low (1992): Genetic survey of Pinus radiata. 6: Wood properties: variation, heritability, and interrelationships with other traits. NZJ For. Sci. 22(2/3): 228-245.

CARSON, S. D. (1991): Genotype x environment interaction and optimal number of progeny test sites for improving Pinus radiata in New Zealand. NZJ For. Sci. 21: 32-49.

Comstock, R. E. and R. H. MolL (1963): Genotype-environment interactions. In: Statistical genetics and plant breeding. Edited by R. E. HANSON and H. F. RoBINSON. NAS-NRC Publ. 982. pp. 53-93.

Cooper, M. and I. H. DELACY (1994): Relationships among analytical methods used to study genotypic variation and genotype-by-environment in plant breeding multienvironment experiments. Theor. Appl. Genet. 88: 561-572.

Cotterill, P. P. and C. A. Dean (1990): Successful tree breeding with index selection. Division of Forestry and Forest Products, CSIRO, Australia. 80 pp.

Costa E Silva, J., B. M. Potts and G. W. Dutkowski (2006): Genotype by environment interaction for growth of Eucalyptus globulus in Australia. Tree Genetics and Genome 2: 61-75.

Costa e Silva, J., H. Wellendorf and H. Pereira (1998): Clonal variation in wood quality and growth in young Sitka spruce (Picea sitchensis (Bong) Carr.): estimation of quantitative genetic parameters and index selection for improved pulpwood. Silvae Genet. 47: 20-32.

Dean, C. A., P. P. Cotterill and J. N. CAmeron (1983): Genetic parameters and gains expected from multiple trait selection of radiata pine in eastern Victoria. Aust. For. Res. 13: 271-278.

Ding, M. M., B. Tier, W. Yan, H. X. Wu, M. B. Powell and T. A. MCRAE (2008): Application of GGE biplot analysis to evaluate Genotype (G), Environment (E) and $\mathrm{GxE}$ interaction on $P$. radiata: a case study. NZJ For. Sci. 38: 132-142.

EISEN, E. and A. SAXTON (1983): Genotype by environment and genetic correlations involving two environment factors. Theoretical and Applied Genetics 67: 75-86.

Gapare, W. J., A. C. Matheson, M. Ivkovic, B. S. Baltunis and H. X. WU (2009) Genetic stability of wood density and diameter in Pinus radiata D. Don plantation estate in Australia. Tree Genet. Genomes 6: 113-125.

Gilmour, A. R., B. J. Gogel, B. R. Cullis and R. Thompson (2005): ASReml User Guide Release 2.0. VSN International Ltd., Hemel Hempstead, HP1 1ES, UK. 267 pp.

Hannrup, B., C. Cahalan, G. Chantre, M. Grabner, B. Karlsson, I. Le Bayon, G. L. Jones, U. Muller, H. Pereira, J. C. Rodrigues, S. Rosner, P. Rozenberg, L. WilHelmsson and R. Wimmer (2004): Genetic parameters of growth and wood quality traits in Picea abies. Scand. J. For. Res. 19: 14-29.

HodGe, G. R. (1996): Marginal gains from regionalization to utilize genotype $\mathrm{x}$ environment interaction variance. In: Dieters, M. J., Matheson, A. C., Nikles, D. G., HaRWood, C. E., and WALKER, S. M. (Eds). 1996 Tree Improvement for Sustainable Tropical Forestry Proceedings QFRI - IUFRO Conference, Coloundra, Queensland, Australia. 27 October - 1 Nov, 1996.

Hodge, G. R. and W. S. DvoraK (1999): Genetic parameters and provenance variation of Pinus tecunumanii in 78 International trials. Forest Genetics 6: 157-180.
Hodge, G. R. and T. L. White (1992): Genetic parameter estimates for growth traits at different ages in slash pine and some implications for breeding. Silvae Genet. 41: 252-262.

Ivković, M., H. X. Wu, T. A. McRAe and M. B. Powell (2006): Developing breeding objectives for radiata pine structural wood production I: Bioeconomic model and economic weights. Can. J. For. Res. 36: 2920-2931.

JAYAWICKRAMA, K. J. S. (2001): Genetic parameter estimates for radiata pine in New Zealand and New South Wales: A synthesis of results. Silvae Genet. 50: 45-53.

JoHNSON, I. G. (1992): Family-site interactions in radiata pine families in New South Wales, Australia. Silvae Genet. 41: 55-62.

Johnson, G. R. and R. D. BuRdon (1990): Family-site interaction in Pinus radiata: Implications for progeny testing strategy and regionalized breeding in New Zealand. Silvae Genet. 39: 55-62.

KuMAR, S. (2004): Genetic parameter estimates for wood stiffness, strength, internal checking, and resin bleeding for radiata pine. Can. J. For. Res. 34: 2601-2610.

LEE, S. J. (1997): The genetics of growth and wood density in Sitka spruce estimated using mixed model analysis techniques. PhD. Thesis, University of Edinburgh, 213 pp.

LI, L. and H. X. WU (2005): Efficiency of early selection for rotation-aged growth and wood density traits in Pinus radiata. Can. J. For. Res. 35: 2019-2029.

Lu, P., D. A. Huber and T. L. White (2001): Comparison of multivariate and univariate methods for estimation of Type B genetic correlations. Silvae Genet. 50: 13-22.

LYNCH, M. and B. WALSH (1998): Genetics and Analysis of Quantitative Traits. Sinauer Associates Inc., Sunderland, MA, USA.

Matheson, A. C. and P. P. Cotterill (1990): Utility of genotype $x$ environment interactions. For. Ecol. Manage. 30: 159-174.

Matheson, A. C. and C. A. RAYMOND (1984): The impact of genotype x environment interactions on Australian Pinus radiata breeding programs. Aust. For. Res. 14: 11-25.

Pederick, L. A. (1990): Family x site interactions in Pinus radiata in Victoria, Australia, and implications for breeding strategy. Silvae Genet. 39: 134-140.

Powell, M. B., T. A. McRae, H. X. Wu, G. W. Dutkowski and D. J. Pilbeam (2004): Breeding strategy for Pinus radiata in Australia. In: LI, B. and McKeAND, S. (Eds). Proceedings of IUFRO Forest Genetic Meeting (Forest genetics and tree breeding in the age of genomics: progress and future), pp 308-318.

Pswarayi, I. Z., R. D. Barnes, J. S. Birks and P. J. KANOWSKI (1997): Genotype-Environment Interactions in a population of Pinus elliottii ENGELM. Var. elliottii. Silvae Genet. 46: 35-40.

RAYMOND, C. A. and G. NAMKOONG (1990): Optimising breeding zones: Genetic flexibility or maximum value? Silvae Genet. 39: 110-112.

RozenberG, P. and C. CAHAlan (1998): Spruce and wood quality: genetic aspects (A review). Silvae Genet. 46: 270-279.

Shelbourne, C. J. A. (1972): Genotype-environment interaction: its study and its implications in forest tree improvement. IUFRO Genet. - SABRAO Joint Sympo., Tokyo, October 1972.

Smith, A., B. Cullis and R. Thompson (2001): Analyzing variety by environment data using multiplicative mixed models and adjustments for spatial field trend. Biometrics 57: 1138-1147. 
Smith, A. B., B. R. Cullis and R. Thompson (2005): The analysis of crop cultivar breeding and evaluation trials: an overview of current mixed model approaches. Journal of Agricultural Science 143: 449-462.

White, T. L., W. T. Adams and D. B. Neale (2007): Forest Genetics. CABI Publishing, CAB International, Wallingford, Oxfordshire, OX10 8DE, UK, 682 p.

White, T. L., G. R. Hodge and G. L. Powell (1993): Advanced-generation breeding strategy for slash pine in the southeastern United States. Silvae Genet. 42: 359-371.

White, T. L., A. C. Matheson, P. P. Cotterill, R. G. Johnson, A. F. Rout and D. B. Boomsma (1999): A nucleus breeding plan for radiata pine in Australia. Silvae Genet. 48: 122-133.
Woolaston, R. R., P. J. Kanowski and D. G. NiKLes (1991): Genotype-environment interaction in Pinus caribaea var. hondurensis in Queensland, Australia. II. Family x site interaction. Silvae Genet. 40: 228-232.

Wu, H. X. and A. C. MAtheson (2005): Genotype by environment interaction in an Australia-wide radiata pine diallel mating experiment: Implications for regionalized breeding. For. Sci. 5(1): 1-11.

Wu, H. X., M. Ivković, W. J. Gapare, B. S. Baltunis, M. B. Powell and T. A. McRAe (2008): Breeding for wood quality and profit in radiata pine: a review of genetic parameters. NZ J. For. Sci. 38: 56-87.

YAMADA, Y. (1962): Genotype by environment interaction and genetic correlation of the same trait under different environments. Japanese Journal of Genetics 37: 498-509.

\title{
Growth Characteristics, Physiological and Metabolic Responses of Teak (Tectona Grandis Linn. f.) Clones Differing in Rejuvenation Capacity Subjected to Drought Stress
}

\author{
By AzAmal Husen*)
}

(Received $8^{\text {th }}$ August 2009)

\begin{abstract}
Summary
Four-year old clones (FG1 and FG11) of teak (Tectona grandis Linn. f.), differing in rejuvenation capacity were grown in glazed earthenware pots. Drought treatments were imposed by withholding water for 20 days and rewatered to the field capacity daily for 5 days and the possible role of biochemical alteration and antioxidant metabolism in conferring photosynthetic capacity was determine by measuring photosynthetic traits, cellular damage and assaying activities of the superoxide dismutase (SOD) and peroxidase (PER) enzymes. Growth, relative water content (RWC), net photosynthetic rate (Pn), stomatal conductance (gs), chlorophyll fluorescence (Fv/Fm) and chlorophyll a, b, total chlorophyll and soluble protein content decreased significantly with increasing drought treatments from 5 to 20 days. Droughtinduced stress significantly increased the carotenoids content, relative electrolyte leakage and malondialdehyde (MDA) content, and, at the same time, accumulated free proline, free amino acid and soluble sugars in both clones. After re-watered to the field capacity daily for 5 days, both clones were shown significant recovery in the studied parameters. As compared with the FG11, the FG1 clone was more tolerant to drought as indicated by higher level of antioxidant enzyme activities as well as lower MDA content and electrolyte leakage. Similarly, drought stress caused less pronounced inhibition of
\end{abstract}

\footnotetext{
*) Department of Biology, Faculty of Natural and Computational Sciences, University of Gondar, P.O. Box 196, Gondar, Ethiopia. Phone: 00251-918-806304. Fax: 00251-58-1141931. E-Mail: adroot92@yahoo.co.in
}

Pn in FG1 than in FG11 clone. After re-hydration, the recovery was relatively quicker in FG1 than in FG11 clone. FG1 clone showed significant recovery in maximum quantum yield or photochemical efficiency of PSII $(\mathrm{Fv} / \mathrm{Fm})$ after 5 days of re-watering. The FG11 compared to the FG1, the former clone was less tolerant to drought than the latter. These results demonstrated that the different physiological strategies including antioxidative enzymes employed by the FG1 and FG11 clones of $T$. grandis to protect photosynthetic apparatus and alleviate drought stress. Furthermore, this study also provides ideas for teak improvement programmes and may be useful in breeding or genetic engineering for their tolerance to drought stress.

Key words: Antioxidative enzymes, Chlorophyll fluorescence, Drought stress, Leaf oxidative damage, Osmolyte accumulation, Photosynthetic capacity, Teak clones.

$\begin{array}{ll}\text { Abbreviations: Car } & \text { Carotenoids } \\ \text { Chl } & \text { Chlorophyll } \\ \text { DW } & \text { Dry weight } \\ \text { E } & \text { Transpiration rate } \\ \text { FAA } & \text { Free amino acid } \\ \text { Fv/Fm } & \begin{array}{l}\text { Maximum quantum yield or photo- } \\ \text { chemical efficiency of PSII }\end{array} \\ \text { FW } & \text { Fresh weight } \\ \text { gs } & \text { Stomatal conductance } \\ \text { MDA } & \text { Malondialdehyde } \\ \text { PER } & \text { Peroxidase } \\ \text { Pn } & \text { Net photosynthetic rate } \\ \text { RWC } & \text { Relative water content } \\ \text { SOD } & \text { Superoxide dismutase } \\ \text { TSP } & \text { Total soluble protein } \\ \text { TSS } & \text { Total soluble sugar }\end{array}$

